\title{
FAKTOR PENYEBAB TERJADINYA INFLASI KERUGIAN PELAKSANAAN PEKERJAAN FISIK JASA KONSTRUKSI
}

\begin{abstract}
Sutirto
Abstrak :

Estimasi Biaya / Rencana Anggaran Biaya ( RAB ) merupakan jumlah total biaya untuk melaksanakan rangkaian kegiatan, yang di dalamnya terdapat seluruh rangkaian item pekerjaan yang akan di laksanakan. Di dalam perhitungan Rencana Anggara Biaya di kalangan jasa konstruksi yang di hitung terdapat 4 ( empat) komponen penting yang harus diperhitungkan yaitu, biaya langsung, biaya tak langsung, biaya tak terduga dan biaya profit. Dengan kepandaiannya para estimator dari ke empat komponen tersebut di masukkan dalam perhitungan $R A B$ yang kadang - kadang tidak nampak dalam perhitungan.

Untuk ketelitian perhitungan Estimasi Biaya di perlukan seorang Estimator yang berpengalaman baik di kantor maupun di lapangan. Hal ini memperkecil kesalahan untuk mengambil langkah -langkah pemikiran yang akan di terapkan dalam bentuk biaya. Keakuratan dalam menganalisis rangkaian pekerjaan dari estimator mempengaruhi dan berdampak terhadap hasil jumlah Rencana Anggaran Biaya ( $R A B$ ). Sering terjadi dan di jumpai pada saat pelaksanaan di lapangan biaya item pekerjaan di estimasi biaya tidak terhitung, padahal pekerjaan tersebut harus di kerjakan.

Hal ini yang menjadi penyebab kurangnya keakuratan dalam menganalisis seluruh rangkaian kegiatan ( pekerjaan ) pada saat menghitung estimasi dalam pengajuan biaya. Perhitungan yang kurang akurat dalam perhitungan Rencana Anggaran Biaya akan menimbulkan kendala pada saat pelaksanaan di lapangan. Bagi estimator yang menjadi kendala pada saat menghitung harga satuan pekerjaan galian tanah, urugan tanah kembali khususnya untuk di pakai di Wilayah NTT akan menyulitkan dalam menganalis perhitungan supaya sesuai harga yang akan di pakai di lapangan. Biaya lain adalah biaya-biaya yang tidak boleh nampak dalam RAB, seperti pembayaran galian $C$, pembayaran Asuransi Tenaga Kerja (Astek) serta biaya pengurusan Ijin Mendirikan Bangunan ( IMB ) yang semuanya di bebankan kepada pelaksana kontrusksi (kontraktor).

Faktor-faktor tersebut sebagai penyebab kerugian bagi para jasa kontruksi (kontraktor), dengan demikian akan mempunyai dampak terhadap mutu dan kualitas pekerjaan di lapangan karena nilai total biaya yang diusulkan harus semua dikerjakan baik yang nampak maupun yang tidak nampak. Bilamana ada klaim dari Pihak kontraktor kepada pihak bouwher, pihak bouwher akan selalu memberi arahan dan petunjuk kompensasi.
\end{abstract}

Kata Kunci : Estimasi Biaya, Factor penyebab kerugian bagi para jasa kontruksi (kontraktor), Mutu dan Kualitas pekerjaan. 


\begin{abstract}
:
Estimated Cost / Budget Plan (RAB) is the total cost to implement a series of activities, which in it there are a whole set of work items that will be conducted. In the calculation of Cost Budget Plan among construction service in the count there are 4 (four) important components that must be taken into account, the direct costs, indirect costs, unexpected costs and expenses profit.

With the cleverness of the estimator of the four components included in the calculation of the RAB that sometimes - sometimes not appear in the calculation. For the calculation accuracy in need of a Cost Estimate Estimator experienced in both the office and in the field. This is to reduce the error to take steps - steps of thinking that will be applied in the form of fees. The accuracy in analyzing the sequence of estimators work influence and affect the result of the Budget Plan (RAB). Common and encountered during field implementation costs in the estimated cost of work items are not counted, but such work should be done.

This is the cause of the lack of accuracy in analyzing the entire set of activities (jobs) when calculating the estimates in the filing fee. The calculation is less accurate in the calculation of Budget Plan will cause problems during implementation in the field. For the estimator is a constraint when calculating the unit cost of soil excavation work, urugan back ground, especially for use in the Territory NTT will be difficult in order to analyze the calculation according to the price that will use the field. Another cost is the cost - a cost that should not be visible in the RAB, such as quarrying $C$ payments, payment of Labor Insurance (Astek) as well as the cost of Building Permit (IMB) which are all in charge of contruction to the performer kontrusksi (contractor).

Factors - such as the cause of the loss factor for construction services (contractor), will thus have an impact on the quality and the quality of work in the field because the value of the total proposed cost must all be done either visible or invisible. Where there are claims from contractors to the bouwher, bouwher parties will always give direction and guidance of compensation.
\end{abstract}

Keywords : Cost Estimation, factor in the loss for construction services (Contractor), the quality and the quality of work.

\section{PENDAHULUAN}

Estimasi biaya merupakan hal penting dalam dunia industri konstruksi, ketidak akuratan dalam estimasi dapat memberikan efek negatif pada seluruh proses kontrusksi dan semua pihak yang terlibat. Menurut Pratt (1995) fungsi dari estimasi biaya dalam industri kontrsuksi adalah: a. Untuk melihat apakah perkiraan biaya konstruksi dapat terpenuhi dengan biaya yang ada. b.Untuk mengatur aliran dana ketika pelaksanaan kontruksi sedang berjalan.

c. Untuk kompetensi pada saat proses penawaran.

Estimasi biaya berdasarkan spesifikasi dan gambar kerja yang dipersiapkan owner harus menjamin bahwa pekerjaan akan terlaksana dengan tepat dan kontraktor dapat menerima keuntungan yang layak.
Estimasi biaya konstruksi dikerjakan sebelum pelaksanaan fisik dilakukan dan memerlukan perhitungan analisis yang detail dari dokumen penawaran dan lainnya. Estimasi biaya mempunyai dampak pada kesuksesan proyek dan perusahaan. Keakuratan dalam estimasi biaya tergantung pada keahlian dan kerajinan estimator dalam mengikuti seluruh proses pekerjaan dan sesuai dengan informasi terbaru. Secara umum komponen biaya yang tercantum dalam estimasi biaya konstruksi meliputi :

a.Estimasi biaya langsung (material, laboratorium dan peralatan).

b.Estimasi biaya tak langsung.

c. Biaya tak terduga.

d.Keuntungan (profit).

Proses analisis biaya konstruksi adalah suatu proses untuk mengestimasi biaya langsung yang secara umum digunakan sebagai dasar 


\section{1 | JUTEKS Jurnal Teknik Sipil Volume 2 Nomor 2 Oktober 2017}

penawaran. Salah satu metode yang digunakan untuk melakukan estimasi biaya penawaran kontruksi adalah menghitung secara detail harga satuan pekerjaan berdasarkan nilai indeks atau koefisien untuk analisis biaya bahan dan upah kerja. Saat ini pada estimator di Indonesia masih banyak mengacu pada BOW (Burgerlijke Open bare Werkenj) yang ditetapkan tanggal 28 Februari 1921 pada jaman pemerintah Belanda. Sudah ada upaya yang dilakukan oleh Puslitbang Permukiman. Departemen Kimpraswil untuk memperbaruhi BOW tersebut dengan membuat Standart Nasional Indonesia ( SNI ), meskipun belum mencakup seluruh jenis pekerjaan. Pada kedua acuan tersebut yang dicantumkan adalah nilai-nilai indeks atau koefisien yang didefinisikan sebagai factor pengali pada perhitungan biaya bahan dan upah kerja tukang pada setiap satuan jenis pekerjaan. Metode ini dapat dilakukan apabila rencana gambar teknis dan persyaratan teknis telah tersedia sehingga volume pekerjaan dapat dihitung.

Pada awalnya estimasi biaya penawaran yang menggunakan panduan tersebut adalah untuk menstandarkan harga bangunan berdasarkan kualitas bangunan yang sama. Hal ini sangat membatasi para estimator apabila harus memperhitungkan berbagai faktor resiko yang berbeda pada setiap daerah. Resiko ketidakseragaman keterampilan tukang, bervariasinya mutu bahan di setiap daerah, kendalakendala teknis lainnya yang mempengaruhi pemilihan metode konstruksi dan lain sebagainya adalah merupakan faktor yang menyebabkan nilai indeks juga berbeda. Pada hal nilai indeks yang tercantum dalam SNI maupun BOW masih menganut nilai tunggal. Perbedaanperbedaan inilah yang akan menjadi kendala biaya operasional pelaksanaan di lapangan. Atas dasar inilah yang menjadi pertimbangan perlunya untuk membuat alat ukur sebagai acuan biaya pelaksanaan di lapangan.

Tujuan daripada penelitian ini adalah : a).Sebagai acuan untuk membuat rencana anggaran biaya pada saat akan memulainya pekerjaan di lapangan; b). untuk memperkecil inflasi biaya dan meningkatkan keuntungan yang lebih besar bagi para pelaksana jasa konstruksi.

Ruang lingkup penelitian ini memberi solusi dan masukan yang menjadi penyebab ketidaksesuaian antara Rencana Anggaran Biaya ( RAB ) dengan biaya operasi-onal yang akan di pergunakan dilapangan. Kesulitankesulitan yang akan di temui estimator pada saat menghitung estimasi biaya fisik kontruksi.

\section{TINJAUAN PUSTAKA}

Analisa biaya konstruksi adalah satuan tahapan yang selalu dilakukan pada saat seorang estimator mengadakan mengestimasi biaya konstruksi yang selanjutnya akan dicantumkan dalam dokumen penawaran. Secara umum dalam dokumen penawaran biaya konstruksi antara pihak konsultan, owner dan kontraktor mempunyai pendetailan yang berbeda. Tetapi perincian biaya yang dicantumkan meliputi dari biaya-biaya sebagai berikut :

a.Biaya langsung (material, tukang dan peralatan).

b.Biaya tak langsung.

c. Biaya tak terduga.

d.Biaya oeverhead, dan keuntungan.

Bagaimana para estimator mengestimasi biaya suatu proyek konstruksi bangunan, untuk mereka yang tidak terbiasa melakukan erstimasi, proses yang harus dijalani terlihat rumit. Seperti memperkirakan jumlah pekerja, jumlah bahan yang di perlukan, jumlah waktu pelaksanaan dan sebagainya.

Selain kesulitan akibat parameter-parameter langsung yang berhubungan dengan biaya konstruksi, terdapat beberapa hal yang juga turut mempengaruhi keakuratan biaya estimasi yaitu waktu dan pengalaman dari estimator.

Mengapa selalu terjadi perbedaan perhitungan antara biaya estimasi dengan biaya actual. Adanya perbedaan yang sering terjadi antara perbedaan biaya estimasi dengan biaya actual disebabkan faktor-faktor dibawah ini : 
a). Perhitungan jumlah volume pekerjaan.

b). Harga material.

c). Upah tenaga kerja.

d). Perkiraan produkstivitas pekerja.

e). Metode kerja.

f). Biaya Peralatan konstruksi.

g). Biaya pekerjaan tak langsung.

h). Biaya untuk supplier material.

i). Ketidak pahaman kondisi lokasi.

j). Biaya untuk sub-kontraktor.

k). Faktor-faktor yang bersifat local.

1). Biaya yang terkait dengan waktu pelaksanaan kontruksi.

m).Biaya-biaya awal pelaksanaan.

n). Overhead.

o). Pertimbangan keuntungan.

p). Alokasi resiko dan biaya tak terduga.

q). Kesalahan dalam rumusan estimasi.

r). Informasi dasar yang biasa digunakan untuk perumusan estimasi biaya.

s). Biaya pembebasan lahan yang kurang jelas.

t). Biaya Pengurusan ijin mendirikan bangunan ( IMB ).

u). Tekanan pasar.

v).Penekanan dari konsultan pengawas untuk diadakan uji karakteristik beton di laboratorium.

w).Ukuran kayu dipasaran yang tidak sesuai dengan ukuran yang didingankan.

Alasan-alasan tersebutlah yang menjadi tugas estimator untuk meminimasi perbedaan tersebut dengan cara memahami rencana proyek, kondisi setempat, dan beberapa faktor resiko lainnya.

\subsection{Metode Estimasi Biaya Konstruksi.}

Dalam melakukan estimasi biaya konstruksi terdapat beberapa 2 metode yaitu :

\section{a.Estimasi Harga Pasti ( Fixed - Price )}

Dalam metode ini dibagi 2 bagian yaitu

Metode Lumpsum ( lumpsum estimate) dan

Metode Harga Satuan ( unit price estimate)

1).Metode lumpsum ( lumpsum estimate) adalah metode yang dilakukan bila jenis pekerjaan dan jumlahnya telah diketahui dan dikenal benar. Kontraktor berani mengambil resiko, dengan ketidakpastian terjadi di lapangan. Maka tingkat resiko yang akan di pikul kontraktor lebih besar. Keuntungan bagi owner adalah harga konstruksi diketahui dengan baik sehingga memudahkan untuk menentukan anggaran.

2).Metode harga satuan biasanya berdasarkan harga satuan setiap pekerjaan. Dalam penawaran juga dicantumkan juga estimasi jumlah setiap jenis pekerjaan untuk mendapatkan total biaya yang mana volume jumlah hanya berdasarkan pada gambar rencana arsitektur yang belum tentu dijamin keakuratannya. Seperti halnya facta cara estimasi lump sum, survey jumlah dibuat untuk setiap jensis penawaran. Biaya total proyek dihitung meliputi tenaga kerja, material, peralatan, sub - kontraktor, overhead dsb.

\section{b.Estimasi Harga Perkiraan ( approximate estimate )}

Metode ini didasarkan fakta perincian biaya dari proyek sebelumnya, adapun yang termasuk dalam metode ini adalah sebagai berikut :

1).Harga per fungsi, metode ini didasarkan pada estimasi biaya setiap jenis penggunaan.

2).Harga luas, metode ini menggunakan harga per luas lantai.

3).Harga volume kubik, metode ini mengacu pada konsep modul dan kemudian dikalikan untuk seluruh proyek.

4).Partial take off, metode ini merupakan jumlah dari gabungan jenis-jenis pekerjaan yang diperkirakan menggunakan harga satuan.

5).Harga Satuan panel, metode ini dilakukan dengan mengasumsikan harga satuan per luas lantai, keliling, dinding, atap dan sebagainya.

6).Harga parameter, metode ini menggunakan harga satuan dari komponen bangunan yang berbeda seperti site work, pondasi, lantai, dinding dan sebagainya. 


\section{JUTEKS Jurnal Teknik Sipil Volume 2 Nomor 2 Oktober 2017}

\section{c.Permasalahan dalam Estimasi Biaya Kontruksi.}

Seorang estimator akan berusaha melakukan estimasi biaya dengan hasil perhitungannya mendekati perhitungan operasional kebutuhan yang actual sesuai penggunaan biaya di lapangan.

Untuk melakukan estimasi biaya suatu pekerjaan sering di jumpai beberapa permasalahan dan kendala yaitu :

\section{1). Memilih Metode Kerja.}

Dalam setiap pekerjaan mungkin terdiri dari beberapa metode kerja, sebagai contoh seorang estimator harus mengasumsikan terlebih dahulu beberapa tukang yang diperlukan dalam melakukan pekerjaan pasangan tembok batu -bata, apakah diperlukan 3 - 4 orang untuk menyelesaikan pekerjaan dengan baik. Bagaimana mengawali pekerjaan tersebut, dan apa saja kendala kendala yang akan terjadi dan harus dihadapi nanti. Semua pertanyaan -pertanyaan tersebut harus dicari solosi dan dipilih yang paling ekonomis.

\section{2). Kebutuhan Tenaga Kerja}

Untuk mengasumsikan kebutuhan tenaga kerja, biasanya didasarkan hasil kenerja pekerjaan sebelumnya dengan pekerjaan yang sejenis. Dengan demikian dokumentasi pekerjaan di lapangan sangat berguna untuk membantu para estimator dalam menganalisa proyek berikutnya. Manipulasi data mungkin tetap diperlukan, misalnya karena terjadi penuruan kondisi pekerjaan.

\section{3). Upah Tenaga Kerja}

Seorang estimator harus memperkirakan biaya yang diperlukan untuk biaya upah tenaga kerja yang terdiri dari mandor, kepala tukang, tukang dan buruh ( pekerja kasar ). Biaya upah tenaga kerja ini akan bervariasi tergantung pekerjaan, keahlian, peraturan upah minimum, kondisi pasar dan sebagainya.

\section{4). Biaya Meterial.}

Hal ini dapat diperkirakan dengan tepat apabila material tersebut tersedia dan banyak di jual di pasaran. Jumlah material yang diperlukan harus dihitung berdasarkan gambar kerja dan tidak tergantung pada kinerja tukang atau metode kerja. Akan tetapi juga diperkirakan material yang terbuang, faktor ini sangat bervariasi dan tergantung pada kinerja dan prosedur kerja yang dipakai oleh tukang.

\section{5). Biaya Overhead dan Keuntungan.}

Biaya ini akan tergantung pada kebijakan perusahaan, kondisi pasar, dan banyak variable lainnya.

\section{d. Pengaruh Lokasi Proyek.}

Perhitungan estimasi biaya konstruksi sangat dipengaruhi oleh lokasi proyek, seorang estimator harus sadar betul bahwa suatu harga dilokasi A yang akan berada di pusat kalau akan berbeda dengan lokasi B yang berada di daerah pegunungan. Faktor lokasi muncul karena terdapat beberapa perbedaan yang menimbulkan kesulitan, seperti :

\section{Keterpencilan kawasan ( remoteness )}

Letak lokasi proyek pada daerah yang terpencil akan mengalami beberapa kesulitan yaitu :

\section{a). Alat Komunikasi.}

Alat komunikasi adalah alat yang sangat diperlukan bila lokasi proyek terletak di daerah terpencil dan jauh dari keramain kota, kesulitan komunikasi dalam melaksanakan pekerjaan proyek adalah masalah yang sangat besar sehingga perlu adanya jaringan telepon atau alat komunikasi lainnya sehingga dalam menghitung estimasi biaya perlu diperhitungkan.

\section{b). Transportasi}

Timbulnya biaya adanya pengiriman karena jarak tempuh pengangkutan material kelokasi dan pengadaan tenaga kerja yang perlu di angkut kelokasi pekerjaan biasanya jarang dimasukkan dalam menghitung estimasi biaya. Bila rute jalan buruk biasa terjadi keterlambatan pengiriman material, serta pada saat mobilisasi alat-alat berat bisa merusak jembatan / deuker dan membuatkan jalan cadangan sehingga diperlukan perbaikan atau membuat jalan cadangan. 


\section{c). Harga Material Berfluktuasi}

Harga material naik biasanya karena naiknya biaya transportasi seperti karena jauh atau kesulitan transportasi.

\section{d). Sumber Listrik dan Air.}

Tenaga listrik dan sumber air selalu diperlukan pada saat pelaksanaan pekerjaan konstruksi. Air diperlukan untuk pengecoran beton, untuk pasangan dan plesteran dan acian pada saat finishing pasangan serta untuk mandi dan minum para pekerja di lapangan. Hal ini tentunya akan menambah biaya konstruksi, demikian juga untuk kebutuhan penerangan. Bila tidak ada aliran listrik di lokasi pekerjaan maka perlu juga di perhitungakan pengadaan generator dan biaya bahan bakar selama pekerjaan berlangsung dan para pekerja berada di lokasi proyek.

\section{e). Keterbatasan lokasi (confined site)}

Lokasi yang terkurung umumnya disebabkan karena kemacetan atau sebab lainnya sehingga lokasi tersebut tidak bebas. Hal ini bisa berakibat produkstivitas pekerja dan alat rendah. Lebih jauh lagi karena keterbatasan lokasi dapat membatasi pemilihan metode kerja, jenis alat yang di gunakan dan jumlah pekerja yang bisa dikaryakan. Dengan keterbatssan ruang gerak, pada awal proyek perlu kehati- hatian dalam menentukan utilitas agar tetap menghasilkan keuntungan yang maksimum dengan menghasilkan produktivitas kerja yang tetap baik. Keterbatasan ruang gerak dapat menimbulkan masalah logistic. Pengangkutan material tidak dapat dilakukan sekaligus, sehingga setiap jenis material perlu diangkut setiap waktu tertentu. Konsisi ini akan memerlukan biaya tambahan. Seorang estimator perlu memahami masalah-masalah logistik disetiap lokasi. Masalah tersebut dapat terjadi karena jalan masuk terbatas, penimbunan material terbatas, penyimpanan peralatan terbatas, kendaraan trailer tidak dapat digunakan. Semua keterbatasan tersebut menyebabkan pembatasan penggunaan jenis peralatan, pengaruh pada efektivitas menejemen pekerjaan, produktivitas pekerja, pembatasan jumlah pekerja. Hal tersebut dapat menimbulkan penambahan biaya konstruksi.

f). Ketersediaan tukang (labor availability) Setiap lokasi mempunyai beragam ketersediaan jumlah tenaga kerja yang terampil dan tidak terampil, tergantung pada kondisi ekonomi local. Jika di lokasi setempat pekerja yang terampil tidak tersedia maka perlu didatangkan pekerja dari luar lokasi. Mendatangkan tenaga kerja dari satu lokasi ke lokasi lainnya akan memerlukan biaya insentif. Besarnya biaya insentif tergantung pada kondisi pasar, jika mendatangkan tenaga kerja dari luar harus disediakan juga akomodasinya.

\section{g). Cuaca ( weather )}

Kondisi cuaca sangat mempengaruhi hasil kualitas kerja yang nantinya berpengaruh juga pada biaya konstruksi. Sebagai contoh pelaksnaan konstruksi yang dilakukan pada tempat tinggi dengan kecepatan angin kencang, akan mempengaruhi penggunaan keran ( crane) dan tambahan perancang sementara untuk menahan dari hempasan angin. Serta hujan yang terus-menerus akan mempengaruhi pengeluaran biaya dengan tanpa ada kemajuan fisik pekerjaan, pengeluaran biaya berupa memberi makan para pekerja. Bila terpaksa harus melakukan kegiatan pekerjaan pada saat musim hujan perlu pengadaan terpal sebagai pelindung bagi tenaga kerja dan hasil pekerjaan yang baru dikerjakan.

\section{h). Pertimbangan design (design considera- tion)}

Lokasi suatu proyek mempunyai beberapa aspek yang harus dipertimbangkan oleh perencana. Sebagai contoh bangunan sejarah, seluruh designnya harus harmonis dengan bangunan sejarah yang ada di lokasi setempat. Pertimbangan penggunaan material dan konfigurasi bangunan perlu 


\section{5 | JUTEKS Jurnal Teknik Sipil Volume 2 Nomor 2 Oktober 2017}

disesuaikan dengan kondisi local. Pertimbangan-pertimbangan ini dapat menimbulkan masalah tersendiri. Seorang estimator harus paham apakah ada persyaratan khusus untuk maneterial, apakah tersedia tenaga kerja local dengan keahlian yang direncanakan, jika tidak maka perlu didatangkan spesialis.

\section{i). Kerawanan dan keamanan lokasi ( vanda lism and site security )}

Keamanan dan kerawanan di lokasi perlu juga diperhitungkan. Misalnya perlu penjagaan selama 24 jam. Tingkat keamanan akan mempengaruhi tingkat resiko pelaksnaan proyek, sehingga kadang kala keamanan setempat perlu dilibatkan.

\section{HASIL DAN PEMBAHASAN}

\subsection{Indeks Biaya Pekerjaan.}

Indeks biaya adalah koefisien pengali yang digunakan dalam analisa perhitungan estimasi dengan metode harga satuan. Harga satuan pekerjaan sesuai dengan definisinya adalah harga yang harus dibayar untuk menyelesaikan suatu pekerjaan konstruksi. Persiapan yang harus dilakukan adalah mempersiapkan gambar teknis secara detail dari konstruksi bangunan yang akan dibangun dan dapat dipahami oleh semua pihak. Persyaratan teknis juga diperlukan untuk mengetahui secara detail mutu bahan dan metoda kerja yang akan direnca-nakan. Selanjutnya dengan memahami sedikit kondisi rencana proyek, diperlukan daftar yang akan digunakan sebagai dasar perhitungan.

Setiap jenis pekerjaan mempunyai harga satuan pekerjaan yang merupakan penjumlahan dari harga satuan masing-masing variable pembentuknya dengan masing-masing indeks biaya. Variabel pembentuknya terdiri dari material ( M ), tukang ( L ) dan peralatan ( E ). Untuk menganalisis indeks biaya berdasarkan data sekunder hasil survey lapangan sangat sulit dilakukan.

Analisis biaya proyek kadangkala sulit untuk memilah-milah biaya pekerjaan murni, karena dalam analisis biaya sudah dimasukkan biaya markup, overhead, pajak, keuntungan maupun biaya lainnya.

Dari hasil pengamatan dilapangan yang terdapat perbedaan nyata dalam format perincian analisis biaya. Hal ini dibedakan berdasarkan kedudukan dari pada perusahaan tersebut, apakah sebagai owner, konsultan perencana atau kontraktor. Format yang digunakan oleh owner maupun konsultan perencana umumnya mempunyai format yang sama, karena perincian kerja disusun berdasarkan kebutuhan perencana pekerjaan konstruksi. Sementara format yang digunakan kontraktor sedikit berbeda karena perincian analisis biaya lebih digunakan untuk pelaksanaan pekerjaan. Pada dukumen data analisis biaya yang disusun oleh kontraktor karena nantinya akan disampaikan pada owner untuk digunakan penawaran ataupun negoisasi, maka analisis biaya yang sebelumnya dimodifikasi formatnya disesuaikan dengan format yang dibutuhkan oleh owner. Kondisi kondisi itulah yang menyebabkan beberapa kesulitan dalam menentukan indeks biaya yang murni diperlukan dalam analisis perhitungan harga satuan pekerjaan konstruksi.

Khusus untuk uraian bahan dasar mempunyai format yang sama, tetapi untuk biaya tukang dan peralatan digunakan format berbeda. Estimasi dari konsultan jenis pekerjaan dibedakan sesuai dengan tingkat keahlian dan satuan yang digunakan adalah oh (orang hari), sementara estimasi dari kontraktor kadangkala digunakan satu kelompok tenaga kerja dengan satuan $\mathrm{m} 3$ atau disesuaikan dengan produktivitas kerja dalam menyelesaikan satu m3 unit pekerjaan beton, sehingga satuan yang digunakan adalah jam. Demikian juga perincian peralatan yang digunakan, pada konsultan digunakan satuan LS ( Lump Sum) sedangkan kontraktor dibedakan jenis alatnya dan produkti vitas kerja alat pada setiap satu satuan volume perbedaan tersebut di atas menerangkan :

-.Pengumpulan data perlu memperhatikan penggunaan format analisis harga satuan perlu dibedakan antara format konsultan dan format kontraktor. 
-.Umumnya indeks biaya untuk material mempunyai nilai sama untuk semua pelaku pekerjaan, baik konsultan maupun kontraktor. Tetapi indeks biaya untuk upah tukang dan peralatan mempunyai nilai dan format yang berbeda disesuaikan dengan metode analisis dan prosedur konstruksi yang digunakan.

\subsection{Estimasi Biaya Penawaran}

Format penawaran biaya yang disusun oleh konsultan, owner dan kontraktor tentunya akan sangat berbeda. Sementara itu bentuk format penawaran antara kontraktor satu dengan yang lainnya juga berbeda tergantung pada pola pelaksanaan pekerjaan, apakah seluruh pekerjaan akan dikerjakan sendiri seperti halnya kontraktor kecil atau beberapa jenis pekerjaan akan disubkan pada kontraktor lainya.

Dalam peruntukan untuk menghitung estimasi biaya ada sedikit perbedaan dalam format analisisnya, yaitu untuk kontraktor sebelum menganalisis biaya perlu menganalisis teknis pelaksanaan karena kontraktor baru mampu memperkirakan lamanya pelaksanaan, sehingga setiap peralatan dan tenaga tukang perlu dianalisis produktivitas kerjannya. Langkah-langkah yang umum digunakan oleh kontraktor dalam melakukan analisis teknis pelaksanaan adalah sebagai berikut :

a). Menentukan metode pelaksanaan.

b). Memperkirakan waktu pelaksanaan.

c). Menghitung keperluan tenaga kerja, bahan dan peralatan.

d). Menetapkan apakah peralatan yang diperlukan perlu dibeli atau disewa.

Pada kedua format perincian biaya antara konsultan dan kontraktor tersebut diatas jelas terlihat bahwa :

a).Dalam pendetailan di pekerjaan persiapan, kontraktor perlu memperinci lebih jelas semua jenis peralatan yang diperlukan dan berbagai keperluan.

b).Hal ini terkait erat dengan perhitungan factor resiko di lapangan selama pelaksanaan proyek. Sementara pada estimasi biaya yang dikeluarkan oleh konsultan tidak mendetailkan semua jenis peralatan ataupun keperluan lainnya. Hal ini terjadi karena ruang lingkup pekerjaan konsultan dan kontraktor berbeda sehingga format dalam estimasi biaya berbeda.

c).Format estimasi yang digunakan konsultan dapat dikategorikan sebagai estimasi design (design estimate), karena metode analis harga satuannya diuraikan dalam system struktur major seperti harga satuan seluruh lantai atau diuraikan lebih detail yaitu harga komponen mayor.

d).Rencana Anggaran Biaya yang disusun kontraktor format estimasi yang digunakan dikategorikan sebagai estimasi penawaran, yaitu pendetailan dilakukan untuk memudahkan dalam penyerahan pekerjaan pada sub-kontraktor.

e).Secara umum total biaya untuk pelaksanaan proyek konstruksi terdiri dari beberapa pekerjaan yang masing-masing terbentuk berdasarkan perkiraan biaya yang dibutuhkan untuk bahan, tenaga kerja dan peralatan yang digunakan, serta biaya-biaya pembayaran retribusi galian C, pembayaran Asuransi Tenaga Kerja (Astek).

\subsection{Ketidak Sesuaian BOW sebagai Dasar Perhitungan}

Ketidak sesuaian BOW sebagai dasar perhitungan untuk item pekerjaan tertentu yang diterapkan di Wilayah NTT, dipergunakan hanya sebagai pelengkap perhitungan walaupun harga satuan tersebut tidak menjangkau sesuai pembayaran dilapangan. Hal ini dengan tanpa disadari sebagai salah satu inflasi pengeluaran dengan pola pemikiran kompensasi dengan pekerjaan yang lain. Sedangkan penetapan harga satuan upah akan berkaitan dengan harga setiap item pekerjaan untuk seluruh komponen kegiatan pelaksanaan.

Dibawah ini penerapan perhitungan untuk pekerjaan galian tanah dan urugan tanah kembali yang di terapkan bagi para kontraktor di Wilayah Propinsi Nusa Tenggara Timur.

Harga satuan upah sesuai pengamatan di lapangan, 2009: 


\section{7 | JUTEKS Jurnal Teknik Sipil Volume 2 Nomor 2 Oktober 2017}

- Pekerja Rp.25.000 / Hari

- Mandor Rp. 40.000 / Hari

$\left(\mathrm{A}_{1}\right) 1 \mathrm{~m} 3$ Pekerjaan Galian Tanah (untuk tanah biasa)

0.75 Pekerja Rp.25.000,00 = Rp.18.750,00

0,025 Mandor Rp.40.000,00 =Rp. 1.000,00

$1 \mathrm{~m} 3$ Galian tanah biasa $=$ Rp. $19.750,00$

$\left(\mathrm{A}_{2}\right) .1 \mathrm{~m} 3$ Pekerjaan Galian Tanah (untuk tanah keras / belincong ) :

2.00 Pekerja Rp. $25.000,00=$ Rp. 50.000,00

0,033 Mandor Rp. 40.000,00 =Rp. $1.320,00$

$1 \mathrm{~m} 3$ Galian tanah keras $=$ Rp. 51.320,00

$\left(\mathrm{A}_{3}\right) .1 \mathrm{~m} 3$ Pekerjaan Galian Tanah (untuk tanah yang banyak terdapat batu-batu bundar )

1.50 Pekerja Rp.25.000,00 = Rp. 37.500,00

0,05 Mandor Rp. 40.000,00 =Rp. 2.000,00

$1 \mathrm{~m} 3$ Galian tanah yang banyak batu bundar

$$
=\text { Rp. 39.500,00 }
$$

$\left(\mathrm{A}_{4}\right) .1 \mathrm{~m} 3$ Pekerjaan Galian Tanah (untuk tanah lumpur )

1.50 Pekerja Rp. 25.000,00 = Rp. 37.500,00

0,05 Mandor Rp. 40.000,00 = Rp 2.000,00

$1 \mathrm{~m} 3$ Galian tanah lumpur $=$ Rp. $39 \cdot 500,00$

A5. $1 \mathrm{~m} 3$ Pekerjaan Galian Tanah (untuk tanah cadas / balincong)

2.00 Pekerja Rp. $25.000,00=$ Rp. $50.000,00$

0,006 Mandor Rp.40.000,00 = Rp 240,00

$1 \mathrm{~m} 3$ Galian tanah lumpur $=$ Rp. 50.240,00

Sumber : Analisa BOW,2008, penerbit Bumi Aksara.

Dari hasil perhitungan diatas bahwa untuk harga pekerjaan galian tanah berkisar antara Rp. 19.750,00 s/d Rp. 51.320,00, sedangkan pekerjaan urugan tanah kembali adalah $1 / 3$ harga galian tanah senilai $1 / 3 \times$ harga galian tanah sebesar Rp. 6.583.33 s/d 17.106.67. Jadi ratarata untuk harga urugan tanah kembali sebesar $((6.583 .33+17.106 .67) / 2))=$ Rp. 11.844,95.

Sesuai pengamatan di lapangan biaya untuk menggali $1 \mathrm{~m} 3$ pekerjaan galian tanah untuk Wilayah Propinsi Nusa Tenggara Timur adalah
Rp. 175.000,00 - Rp. 200.000,00 dan urugan tanah kembali sebesar $1 / 3 \times((175.000+$ 200.000)/2).= Rp. 62.500,00

Untuk item pekerjaan galian tanah dan urugan tanah kembali, terjadi inflasi yang tidak dirasakan oleh para kontraktor sebesar :

a.Pekerjaan Galian tanah = Rp. 200.000,00 Rp. $51 \cdot 320,00=$ Rp. $148.680,00$ dengan prosentasi inflasi Rp. 148.680,00 / Rp. $51.320 .00 \times 100 \%=289.71 \%$ untuk setiap $1 \mathrm{~m} 3$.

b.Pekerjaan Urugan tanah kembali $=\mathrm{Rp}$. $62.500,00$ - Rp. $11.844,95=$ Rp. 50.655,05 dengan prosentasi inflasi Rp.50.655,05 / Rp. $11.844,95 \times 100 \%=23,38 \%$ setiap 1 $\mathrm{m} 3$.

\subsection{Biaya-Biaya Lain yang menjadi Penye- bab Tejadinya Inflasi Biaya}

Penyebab terjadinya inflasi biaya dalam pelaksanaan adalah terjadinya biaya-biaya yang tidak termasuk dalam perhitungan dalam proses penyusunan dalam Rencana Anggaran Biaya (RAB) pada saat mengajukan penawaran.

Biaya ini tidak boleh dimasukkan pada item pengajuan dalam hal ini $B Q$, tetapi kenyataan pada saat pelaksanaan dilapangan harus di bayarkan. Sesuai pengamatan dilapangan pengeluaran biaya ini berkisar antara 2,5 - 5\% di luar dari harga reil cost

Adapun biaya tersebut adalah sebagai berikut :

a.Biaya pengurusan Perijinan Mendirikan Bangunan (INB).

b.Biaya pembayaran Asuransi Tenaga Kerja (ASTEK).

c. Biaya Retribusi Galian C.

d.Biaya pembuatan Barak Kerja.

e. Biaya pengujian material yang akan di pakai. f. Biaya rapat koordinasi di lapangan.

g.Biaya pembuatan laporan pemakaian bahan dan peralatan di lapangan.

\section{KESIMPULAN}

1.Penggunaan nilai tunggal sebagai nilai indeks atau koefisien pengali dalam analisa biaya 
konstruksi seperti yang tercantum dalam SNI kumpulan analisa biaya konstruksi tahun 2002 dapat menyulitkan pada estimator dilapangan, hal ini terlihat dari hasil kompilasi data di lapangan terdapat perbedaan yang signifikan.

2.Banyak alasan yang mendasari tindakan memodifikasi nilai indeks tersebut antara lain karena perhitungan faktor resiko di lapangan, secara umum perbedaan nilai indeks yang paling menyolok adalah nilai indeks untuk perhitungan upah tukang dan biaya peralatan.

3.Acuan perhitungan analisa biaya konstruksi yang digunakan masih banyak yang menggunakan panduan BOW meskipun mereka para estimator menganggap bahwa indeks atau koefisien pengali tidak relevan lagi dengan kebutuhan analisis pekerjaan. Metode yang digunakan untuk mengantisipasi hal ini adalah dengan melakukan modifikasi nilai indeks yang diambil berdasarkan pengalaman kerja. Sementara SNI analisa biaya konstruksi yang diresmikan tahun 2002, umumnya belum digunakan sebagai acuan karena dianggap belum digunakan sebagai acuan karena dianggap belum dikenal secara umum dan belum mengakomodasi semua jenis pekerjaan. 4.Sesuai pengamatan di lapangan biaya untuk pekerjaan galian tanah dan urugan adalah sebagai faktor penyebab inflasi biaya pelaksanaan di lapangan dengan jumlah masing-masing inflasi sebesar pekerjaan Galian tanah 289,71\% dan pekerjaan urugan tanah kembali dengan prosentasi inflasi $23,38 \%$ per $1 \mathrm{~m} 3$.

5. Terjadinya inflasi karena penyebab dari biayabiaya yang tidak boleh di usulkan pada saat penawaran dalam item BQ. Besarnya inflasi berkisar antara 2,5 - 5\% dari jumlah total biaya pelaksanaan pekerjaan.

\section{DAFTAR PUSTAKA}

Analisa Upah dan Bahan (Analisis BOW) Cetakan kesebelas, 2008, penerbit Bumi Aksara.

Andy Kirana, 1996, Etika Bisnis Konstruksi.

Hendrickson, Chris, 2003, Project Managemen for Contrus\ction, Departement of Civil and Environmental Engineering, Carnegie Mellon University, Pittsburgh.

Peurifoy, Robert L and Oberlender, Garold D, 2002, Estimating Construction Costs Mc Graw Hill, Fifth Edition.

Puslitbang Permukiman, 2004, Laporan Final Kajian Indeks Biaya Konstruksi Pekerjaan Beton Bertulang, Baja dan Bahan Komposit untuk bangunan gedung.

Laporan Proyek Pengembangan Teknologi Permukiman dan Perkotaan, 2004, Departemen Kimpraswil, Balitbang, Puslitbangkim.

Sinclair, Neil, Philiphs Artin, Stewart Mulford, 2002, Construction Cost Data Workbook, Conference on the Internastional Comparison Program World Bank, Washington. 